\title{
腹部超音波画像解析による小腸の消化活動活性度評価法
}

\author{
阪田 治 ${ }^{1, \dagger}$ ，鈴木 裕 $^{2}$, 松田兼一 ${ }^{1}$, 佐竹隆顕 ${ }^{3}$ \\ ${ }^{1}$ 山梨大学医学工学総合研究部, ${ }^{2}$ 山梨大学総合分析実験センター, ${ }^{3}$ 筑波大学生命環境科学研究科
}

\section{Evaluation of Digestive Activation Level of a Small Intestine by Abdominal Ultrasound Image Analysis}

\author{
Osamu SAKATA ${ }^{1, \dagger}$, Yutaka SUZUKI ${ }^{2}$, Ken-ichi MATSUDA ${ }^{1}$, and Takaaki SATAKE ${ }^{3}$ \\ ${ }^{1}$ Interdisciprinary Graduate School of Medicine and Engineering, University of Yamanashi, 4-3-11, \\ Takeda, Kofu, Yamanashi 400-8511, Japan \\ ${ }^{2}$ The Center for Life Science Research, University of Yamanashi, 1110, Shimokato, Chuo, Yamanashi 409-3898, Japan \\ ${ }^{3}$ Graduate School of Life Environmental Sciences, University of Tsukuba, 1-1-1, Tennoudai, \\ Tsukuba, Ibaraki 305-8572, Japan
}

\begin{abstract}
Innovating a new food evaluation technique based on biological information must allow us to develop high-valued food products on the occasion of food design. We particularly focus on a small intestine and assume that the digestive activity varies depending on an individual constitution, health condition and compatibility between an individual and a food. We have studied a method to estimate the activity level of peristaltic movements of a small intestine using an ultrasonograph. Ultrasonograph is widely prevalent and the systematized techniques to observe morphology and motion of digestive tracts have been highly established. They are inherently established not to investigate body organs and tissues of a healthy human for objectives being not concerned in disorders but to diagnose body organs and tissues with organic or functional disorders. However, for the new food design, we need to develop a new technique to monitor digestive activity of people with various physical conditions: healthy people, the elderly, patients with lifestyle-related diseases and patients who are critically ill. Therefore, we propose a new technique to analyze digestive activity of a small intestine by timevarying ultrasound image processing. The new technique helps us to quantitatively analyze the appearance that a small intestine transfers digested materials.
\end{abstract}

Keywords: ultrasound image, small intestine, digestive activity, food design

1. 緒言

人間の小腸は消化の際に蠕動運動を行い，これは不 随意筋の働きによって意思とは関係なく進行する。し かし，誰しも小腸の蠕動運動の活性の変化を漠然と感 じることがあり，そしてその変化は損取した食品の性 質やその時の体調，あるいはその食品と自分の体との 相性から影響を受けることを経験的に知っている。こ の原因は小腸の蠕動運動に由来する振動感や, 膨満感, 消化物の移動感などの感覚であると考えられる．小腸

(受付 2010 年 12 月 26 日, 受理 2011 年 6 月 9 日)

1 于400-8511 山梨県甲府市武田4-3-11

2 个409-3898 山梨県中央市下河東1110

3 † $305-8572$ 茨城県つくば市天王台1-1-1

† Fax: 055-220-8684, E-mail: osakata@es.yamanashi.ac.jp
の消化活動の動的特性は可観測な情報であり，客観的 な指標を用いて皃れを定量的に評価する技術があれば， その技術を用いて掑食者の体質・掑食者の体調・消化 物の性質という三者間の相性を調べることが可能にな る。ただし，ここで言う消化物の性質とは，掑取した 食品の物理特性・化学特性・栄養特性・薬理的特性な ぞを意味する。摂取した食品の物理・化学・栄養・薬 理的特性と個人の体調・体質の相性を定量的に評価す ることが可能になれば，高付加価值食品プロダクトの 開発や生活習慣病患者の食事管理、様々な疾患による 入院患者の栄養管理など, 広範囲にわたる食品デザイ ンに非常に役立つと考えられる。 そこで，医療用の超 音波診断装置で非侵襲撮影可能な 2 次元の腹部断層動 画像（B-mode 動画像）を用いて小腸の蠕動運動の活 性度を定量的に評価する技術の研究開発を試みた。一 
般に，小腸はその形状をはっきりと B-mode 画像とし て捉えることが困難であるとされているが，小腸内を 移動する消化物は B-mode 動画像中に観察することは 可能である. 本研究では, 小腸内の消化物の移動を分 析することで，間接的に小腸蠕動運動の活性を調べて いる. B-mode 画像は，1枚あたり数十ミリ秒で連続的 に取得できるため，通常は動画像としてリアルタイム 録画が行われる。本研究では, B-mode 動画像をデジ タル動画として PC に取り込み, PC 上でデジタル画像 処理を行った。

一方，小腸の蠕動運動の活性を生体信号解析に基づ いて評価する試みは他にも行われている。少腸は食物 の消化の際に蠕動運動を行い，それに伴い腸音とよば れる特徴的な音を発生させる。阪田らは腸音の発生頻 度に注目し，その経時変化を時系列信号として解析し， 摂食者の体質・組食者の体調・消化物の性質という三 者間の相性に関してデータマイニングを試みている [1-6]. この腸音モニタリング技術が数時間から数十時 間に打よぶ長期的な小腸蠕動運動活性度の変化を調心゙ る手法であるのに対し，本論文で提案する技術は，任 意の時刻における数秒から数十秒の単位での瞬間的ま たは短期的な小腸蠕動運動活性度を調べる手法である という点で大きく異なる.

また，この他にも小腸の蠕動運動を観察することが 可能な技術として, 医療機関で比較的古くから行われ ている小腸に造影剤を注入しての X 線動画撮影や，力 メラ内蔵小型カプセルなどがある $[7,8]$. これらは腸音 解析や超音波断層動画像解析による方法と比較して, とくに空間分解能に優れている。他にも，高精細な光 学写真の取得やリアルタイムに腸管内の物体移動の観 察が可能であるなどの特徴をもつ。しかし，どちらの 技術も肉体に対して侵襲的であり，かつ精神的にも極 めてストレスの高い非日常の状態を被験者に強制する ものであるため，我々が念頭に置く食品デザインへの 利用には不向きである. 我々が求める食品デザイン法 が，日常生活に打ける自然な消化活動を観察するとい う点を必須とするためである。そこで，非侵襲計測可 能であることを最優先条件とし, 腹部超音波動画像を 用いた小腸蠕動運動定量分析技術の研究開発を行った。 なお，本論文で提案する方法は，先行研究である長時 間腸音モニタリング法 [1-6] との併用を念頭に置いて おり，互いに補完し合うことにより極めて効果的な腸 管活動活性度評価を行うことができると期待している. たとえば食品プロダクトデザインにおいて，試作食品 摂取後に長時間腸音モニタリングを継続的に行い，そ こに超音波動画像記録・解析を適宜挿入して任意の夕 イミングにおける小腸蠕動運動の瞬間的活性を調べる とともに被験者の体調や精神状態を詳細に記録する. そこで得られる小腸蠕動運動の活性の程度や変化に基
づいて, 損取した食品の栄養成分調整や調理・加工法 の検討や，または水分補給・投薬判断といったその食 品の摂取条件設計などをより安全かつ効率的に行える ようになると考えている.

本論文では，前述の目標を達成するための新たな一 手段として，象徴の蠕動運動の様子を間接的に捉えて いる超音波動画像 (B-mode 動画像) の解析・利用法 を提案する.さらに，提案法によってどのような分析 結果が得られるのかについて，具体例をいくつか紹介 する。

\section{2. 超音波動画像解析による小腸蠕動運動定量評価法}

\section{1 処理の流れ}

超音波動画像取得から腸管運動の活性度推定までの 一連の処理の流れについて説明する。次の (a) 〜 (i) の手順に従って行い, 各手順はコンピュータ上で自動 的に行わ机る部分と, 撮影者または解析者が手動で行 う部分がある。

（a）医療現場で一般的に行われる超音波診断と同様に B-mode 動画像として下腹部内を描出する。（同時に可 能な限り高い空間分解能設定下で録画を行う)

（b）プローブの位置や角度を適宜調節しながら，消化 物の移動の有無を確認する。（ある程度の時間が経過し たところで録画を停止する)

(c) 通常は動画像の記録時間全体にわたって継続的に 消化物の移動が見られるとは限らないため，録画され た B-mode 動画像を再生し, 解析者が消化物移動が観 察できる部分を目視で判別し，その消化物移動持続時 間区間を切り出す.

（d）（c）で指定された B-mode 動画像を，これを構成 する 1 静止画ごとに独立した画像ファイルとして PC 上 に保存する.

(e) 一連の B-mode 静止画像中に含まれる撮影時の手 ブレの影響を軽減させる.

（f）通常は動画像の画面全体で消化物移動が見られるわ けではなく，限定された小領域内で消化物の移動が見 られる。そのため，解析者がその範囲および消化物の 動きのみを捉えて次の $(\mathrm{g})$ の計算量の軽減を困るため に, 各 B-mode 静止画像に対し, 消化物の描画領域以 外を取り除くマスク画像処理を行う。

(g) 一連の B-mode 動画像について，時間軸上で前後 に隣り合う 2 枚の静止画間におけるオプティカルフロー [9-14] を計算する.

(h) (g) で求めたオプティカルフローに対して，すべ てのオプティカルフローベクトルのノルムの総和を求 め，これをその 2 枚の静止画間の消化物移動の程度と して単一のスカラ量で表現する.

（i）（h）で求めたスカラ量をすべての前後する 2 枚の 静止画間で求め，これを，横軸を時間軸とする時系列 
として視覚化する．消化物の移動の速さから導かれるこ のグラフを間接的に小腸蠕動運動の活性度として扱う.

以降，これら（a）から（j）の処理の詳細について説 明する。

\section{2 画像取得}

これは，前節に示した処理の流れの（a）から（d） に相当する。

B-mode 動画像の撮影は人間がすべて手動で行う。 その方法は医療現場で通常行われる腹部超音波断層像 撮影と同様で，被験者への注意・指示の与え方からプ ローブの当て方・加減や角度調節，描出の際の画像 補整までを撮影者が適宜行う。

消化物の移動は常に連続的に観測できるものではな いため，撮影者が勘と注意力を頼りに根気良く探す必 要がある。通常は数十秒の撮影で十分な量の消化物移 動動画が得られる。これをデジタル動画として PC 上に 取り込む.さらに，動画を 1 枚（1フレーム）ごとに抽 出し，デジタル静止画として PC 上に保存する。本論文 で紹介する実施例では，動画 1 秒間につき 30 枚の連続 静止画像が得られている.

\section{3 取得画像補正}

2.1 節に示した処理の手順中の（e）の部分であり， これは PC 上の画像処理として行われる。超音波動画像 中の消化物の移動は，固定箇所で連続して長時間見ら れるものではなく，同一箇所にプローブを固定した状 態で見られる 1 回の消化物移動の持続時間は数秒程度 である。そこで，前節で述べた画像取得の際に数秒ご とにプローブの位置・向き・角度を少しずつ変えて撮像 することが必要となる。そのため，1回の撮影でプロー ブ位置・角度を動かす回数が多くなり，画面のブレが 増加する。さらに通常生じる細かな手ブレが加わる. この後に消化物の移動のみに注目して画像処理を行う ために，これらの画面全体のブレと消化物の移動を区 別しておくことが望ましい。

時間の異なるフレーム間に含まれるブレの影響を軽 減して新しいビデオシーケンスを作成するために，イ メージレジストレーションを行う。[15-18] その処理の 概要を Fig. 1 に示す。この方法では，基準となるフレー ム (Base Image; Fig. 2) 内の特徵的な点（コントロー ルポイント）をいくつか設定し（Fig. 3)，コントロー ルポイントを Base Image に続く各フレーム (Following Image; Fig. 2) を通した不動点として扱い，コントロー ルポイントが Base Image フレーム内と同じ位置にくる ように各 Following Image フレームに対して空間変換 （拡大・縮小，回転，平行移動）を施す (Fig. 1).

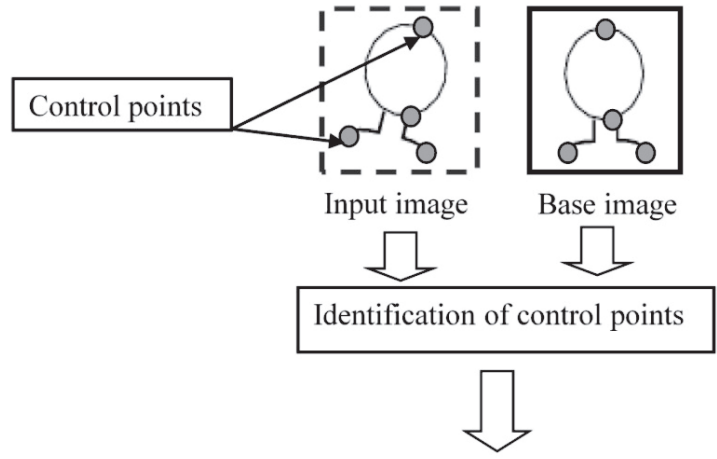

Spatial transformation of the input image

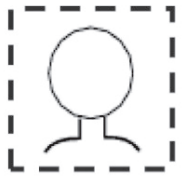

Corrected image

Fig. 1 Correction process of shift and rotation caused by probe shakes.

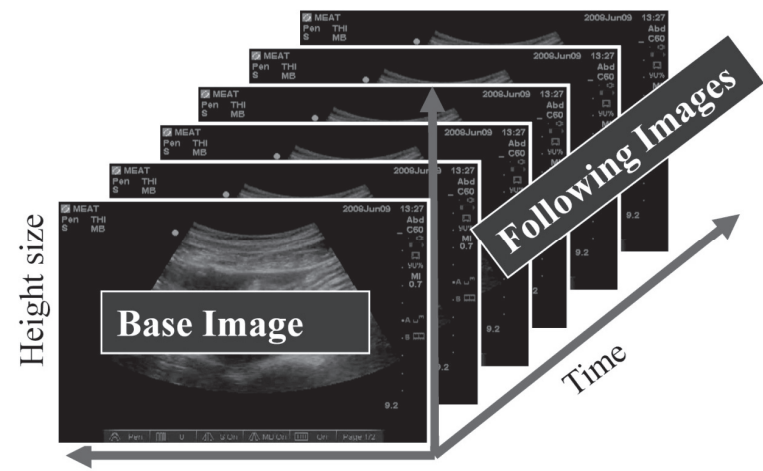

Width size

Fig. 2 Base image and following image.

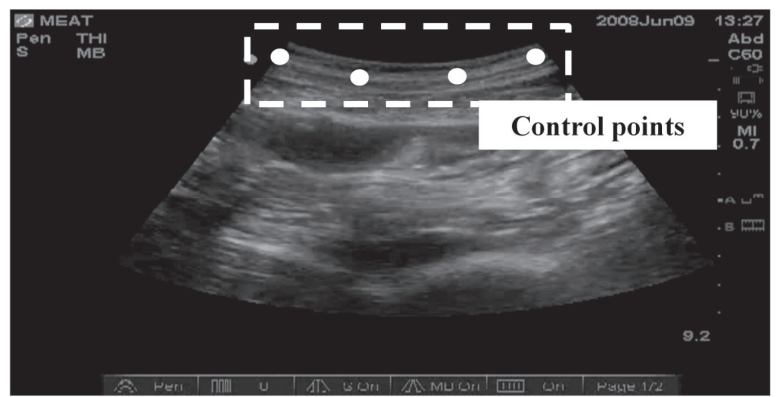

Fig. 3 Control points for correction of image shift and rotation. 


\section{4 消化物の動き検出}

2.4.1 関心領域（Region of interest: ROI）の特定 描出される消化物移動の様子は被験者の体調や個人 差によって大きく異なる．断層画像全面にわたって至 る所で連続的に消化物移動が映し出される場合から, プローブの位置や向きを変えながら根気よく走査して ようやく画面内の一部小領域で観察される場合まで, 様々なケースが見られる。本画像処理は基本的に計算 量が多く，その計算量に比例して大きな計算時間を要 する。そのため，実用上可能な限り計算資源の節約す ることが望ましい。そそこで，撮影者の手で行う計算量 削減のための手続きが関心領域（ROI）の設定である. 録画された数秒から数十秒間の B-mode 動画像の中か ら, 解析対象とする範囲を解析者が手動で設定する (Fig 4)。通常，医療用の超音波診断装置には，本研究とは 異なる用途ではあるものの，画像処理対象領域を選択 するためのユーザインタフェースが備えられている. 我々が開発を目指している手法は，そのような一般的 なユーザインタフェースを活用することが可能であり， 超音波診断装置のハードウェアを改造することなしに， ソフトゥェアの追加だけで実用化が可能となるはずで ある。

\subsection{2 マスク処理}

2.4.1の ROI 設定によって解析範囲が限定されること で，消化物移動以外に起因する B-mode 画像変化の影 響およびオプティカルフロー処理の計算量を大幅に削 減することができる。さらに，ROI 内において可能な 限り余計なものを含まず，理想的には消化物のみに対 してオプティカルフロー計算を行いたい。そこで，ROI 内の消化物描出領域以外を大まかにオプティカルフ ロー解析の対象外とする処理をここで行う.

Fig. 5 (a) は，ROI 内のピクセルの輝度值の頻度を 表すヒストグラムの例である。予備実験を行った経験

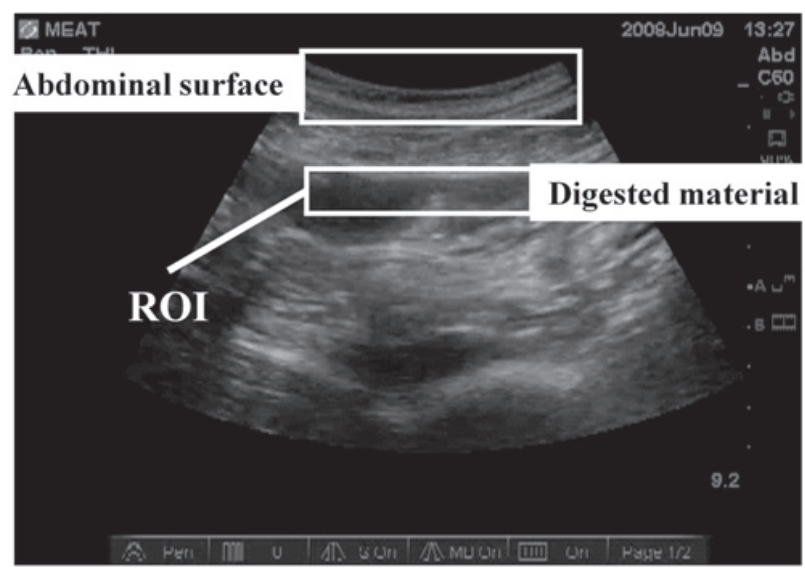

Fig.4 An example of designated ROI for analysis, where digested material can be clearly observed.
上，B-mode 画像中で消化物の移動が確認できる範囲 を矩形 ROI として設定すると，消化物は ROI 内で比較 的高輝度で描画されることが多い。そこで，ROI 内で 録画時間中の平均輝度が適当な閾值以上となる範囲の みをオプティカルフロー処理の対象とするために， マ スク処理を行う。具体的には，Fig. 5 (b) に示す ROI 上で移動する消化物の輝度を基準としてこれが抽出さ れるように適当な輝度閾值を決め，その閾值をもって ROI 内の各ピクセルの録画時間中の平均輝度に対して の 2 值化を行う。この 2 值化画像の黒領域をマスク部, 白領域を透過部とするマスク画像（Fig. 5 (c)）を作成 する。このマスク画像を元の ROI 上に重畳して作られ る画像に対して，次のオプティカルフロー処理を行う.

なお，撮影時に最も消化物の移動がよく観察できる よう画面全体の輝度調整（コントラスト調整およびブ ライトネス調整）を撮影者が自ら行い，この調整值を 基にして消化物とそれ以外を区別するための輝度閾值 が経験的に決定される。通常の医療検査においては, B-mode 画像撮影時に撮影者が必ず手動で輝度調整を 行うが，本研究に扎いてもこれに準ずる。

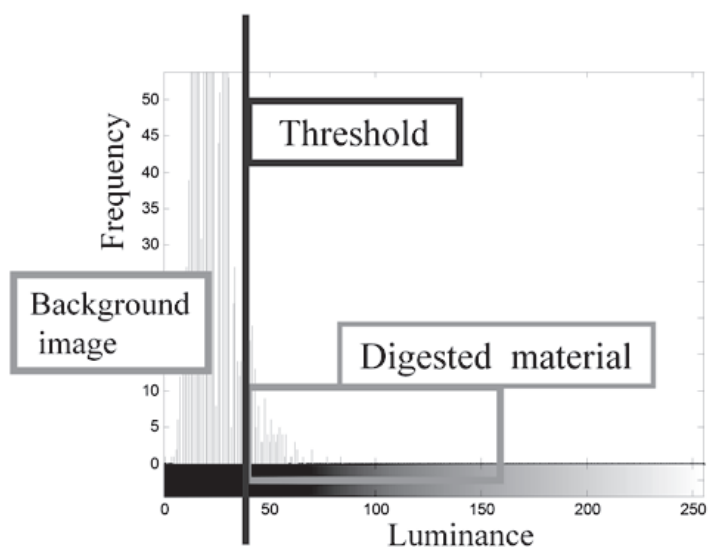

(a)

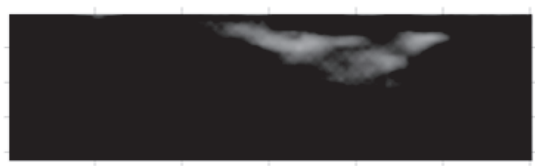

(b)

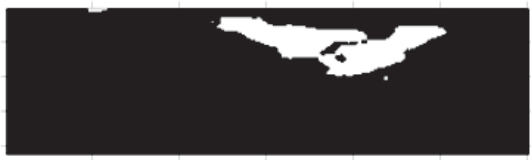

(c)

Fig. 5 Mask extraction of analytic area. (a) Histogram of raw B-mode image. (b) Raw B-mode image. (c) Mask image formed of the analytic area. 


\subsection{3 オプティカルフロー処理}

小腸の螨動運動の様子を定量的に分析するためには， 小腸内を移動する消化物の複雑な動きの大きさを 1 つ の物差しで数值化することが必要になる。 マスク処理 によって消化物描出範囲を大まかに抽出した画像を用 いて，消化物の動きの大きさを計算する。ここでオプ ティカルフローを利用する。[10-14] オプティカルフ ローには様々な計算法があるが，ここでは勾配法とよ ばれる算出法を採用した。

オプティカルフローとは，動画像中の物体の動きをべ クトルで表したものである. 本研究で行ったオプティカ ルフロー処理では，時間的に前後に隣り合う 2 枚の静止 画像（フレーム）間における消化物の移動量をべクトル データとして表現する。ここでは, 連続する 2 枚のフレー 厶間で消化物の移動量が微小，かつ消化物の輝度が移動 後も変化しないことを仮定してオプティカルフローを求 める。このような仮定を打く方法が勾配法であり，「物 体上の点の明るさは移動後も変化しない」という仮定か ら時空間微分とオプティカルフローとの関係式を導出 し，それを利用して対象の動きを推定する。以下に本研 究で用いたオプティカルフロー処理 [11] のアルゴリズム について簡単に説明する。

まず，時刻 $t$ における B-mode 画像上の点（ピクセル） $(x, y)$ の輝度值を $I(x, y, t)$ とし，微小時間 $\Delta t$ 後に画像中 の物体が $x$ 方向と $y$ 方向にそれぞれ微小量 $\Delta x, \Delta y$ だけ移 動したとする．このとき，画像中の移動物体上の点の明 るさが移動後も変わらないとすると,

$$
I(x, y, t)=I(x+\Delta x, y+\Delta y, t+\Delta t)
$$

が成り立つ。（1）式の右辺を Taylor 展開すると，

$$
I(x, y, t)=I(x, y, t)+\Delta x \frac{\partial I}{\partial x}+\Delta y \frac{\partial I}{\partial y}+\Delta t \frac{\partial I}{\partial t}+e
$$

となる.ここで, $\Delta x, \Delta y, \Delta t$ に関する高次の項 $e$ を無視し， 式（2）の両辺を $\Delta t$ で割り， $\Delta t \rightarrow 0$ とすると，

$$
(\nabla I)^{T} \mathbf{p}+I_{t}=0
$$

という基本拘束式が得られる.ただし， $\nabla I=\left(\frac{\partial I}{\partial x}, \frac{\partial I}{\partial y}\right)^{T}$, $I_{t}=\frac{\partial I}{\partial t}$ とし, $\mathbf{P}=\left(\frac{d x}{d t}, \frac{d y}{d t}\right)^{T}$ は画像中の局所領域内の各 点のオプティカルフローである.

求めるオプティカルフロー $\mathbf{P}$ は，パラメータを 2 個 もつため，これを 1 つの基本拘束式から一意に決定す ることはできない。そこで，ある空間的な局所領域内 のオプティカルフローを一定と仮定することにより， 問題の正則化をはかる.

この空間局所領域内に $\mathrm{N}$ 個の点がある場合，（3）式の
基本拘束式から次に示す $\mathrm{N}$ 個の観測方程式が導かれる。

$$
\begin{gathered}
\left(\nabla I_{1}\right)^{T} \mathbf{p}+I_{1 t}=0 \\
\left(\nabla I_{2}\right)^{T} \mathbf{p}+I_{2 t}=0 \\
\vdots \\
\left(\nabla I_{k}\right)^{T} \mathbf{p}+I_{k t}=0 \\
\vdots \\
\left(\nabla I_{N}\right)^{T} \mathbf{p}+I_{N t}=0
\end{gathered}
$$

ただし， $\left(\nabla I_{k}\right)^{T} \mathbf{p}+I_{k t}=0$ は局所領域内の $k$ 番目の点 に関する観測方程式である。

ここで,

$$
\mathbf{A}=\left[\begin{array}{c}
\left(\nabla I_{1}\right)^{T} \\
\left(\nabla I_{2}\right)^{T} \\
\vdots \\
\left(\nabla I_{k}\right)^{T} \\
\vdots \\
\left(\nabla I_{N}\right)^{T}
\end{array}\right], \quad \mathbf{b}=\left[\begin{array}{c}
I_{1 t} \\
I_{2 t} \\
\vdots \\
I_{k t} \\
\vdots \\
I_{N t}
\end{array}\right]
$$

とおくと

$$
\mathbf{A p}+\mathbf{b}=\mathbf{0}
$$

が得られる． $\mathbf{A}^{T} \mathbf{A}$ の逆行列が存在すると仮定すると， 最小二乗法により式（5）からオプティカルフローPを 求めることができる。

$$
\mathbf{p}=-\left(\mathbf{A}^{T} \mathbf{A}\right)^{-1} \mathbf{A}^{T} \mathbf{b}
$$

\subsection{4 小腸蠕動運動活性度評価}

前節で求めたオプティカルフローを用いて，小腸の 蠕動運動の活性度評価を行う。 ROI 内に描かれている $\mathrm{n}$ 本のオプティカルフローベクトルを $\mathbf{p}_{k}=\left(V_{x}^{(k)}, V_{y}^{(k)}\right)^{T}$, $(k=1,2, \cdots, n)$ とするとき，小腸蠕動運動活性度評価指 標 PAを（5）式のように定義する.

$$
P A=\frac{\sum_{k} \sqrt{\left(V_{x}^{(k)}\right)^{2}+\left(V_{y}^{(k)}\right)^{2}}}{X_{R O I} \times Y_{R O I}}
$$

$X_{R O I}$ : 矩形 ROI の横の長さ $Y_{R O I}$ : 矩形 $\mathrm{ROI}$ の縦の長さ

PA は，時間軸上で連続する 2 枚の B-mode 静止画像 間のオプティカルフロー困に含まれる全べクトルのノ ルムの総和である.

\section{3. 実験}

\section{1 実験仕様}

提案手法の実行例として，健常被験者の腹部超音波 
動画像解析を行った。超音波断層動画像記録には市販 の超音波診断装置（M-turbo, Sonosite 社製）を使用し， プローブは同機専用コンベックス型プローブを選択し た。被験者は健常成人男性 3 名（平均 $22 \pm 0$ 歳），昼食 後約 3 時間 30 分経過時に数十秒間の動画撮影を行った. 被験者はベッドの上に仰臥位で安静状態を保ち，Fig. 6 に示す位置にプローブを当てた。B-mode 動画は画面 （フレーム）の縦横サイズが $256 \times 256$ ピクセル，256 階

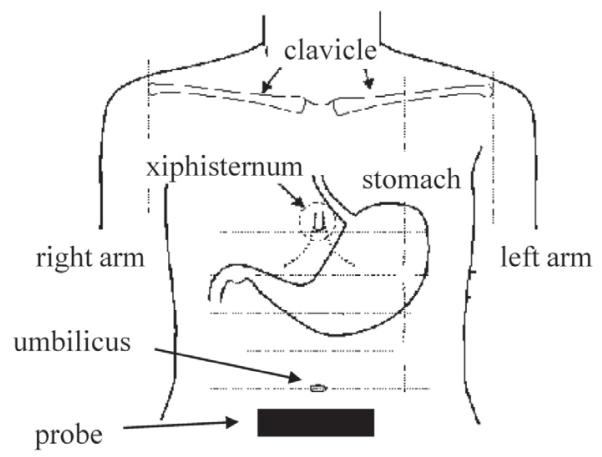

Fig. 6 Standard location of ultrasound probe.
調のグレースケール画像として，毎秒 30 フレームの速 さで録画された。撮影時の装置のコントラスト扎よび ブライトネスは，撮影者の経験に基づき，消化物の移 動が明確に映し出されるよう主観的に最適と考えられ る状態に調整した。撮影深度は，小腸の運動が十分に 捉えられる深度として 0 9 cm に設定した。

\section{2 実験結果}

提案法により，3名の被験者から記録した B-mode 動画像の解析を行った。その中から，連続する 2 フレー ム間のオプティカルフロー四を数例 Fig. 7 に示す.も ちろん Fig. 7 に示す例以外にも, 様々なパターンがある. Fig. 7 (a) は，ROI 全体にわたって 1 つの大きな消化 物の流れが観察される例である。Fig. 7 (b) は， ROI 全体に均等にゆっくりとした 1 方向の流れが観察され る例である. Fig. 7 (c) は，ROI 中で流れが蛇行して いる例である．Fig. 7 (d) は，ROI 中で特定の領域に 流入している様子を表していると考えられる. Fig. 7 (e) は，ROIのほぼ中央辺りを中心として渦を形成してい る例である．Fig. 7 (f) は，消化物の大きな移動がある
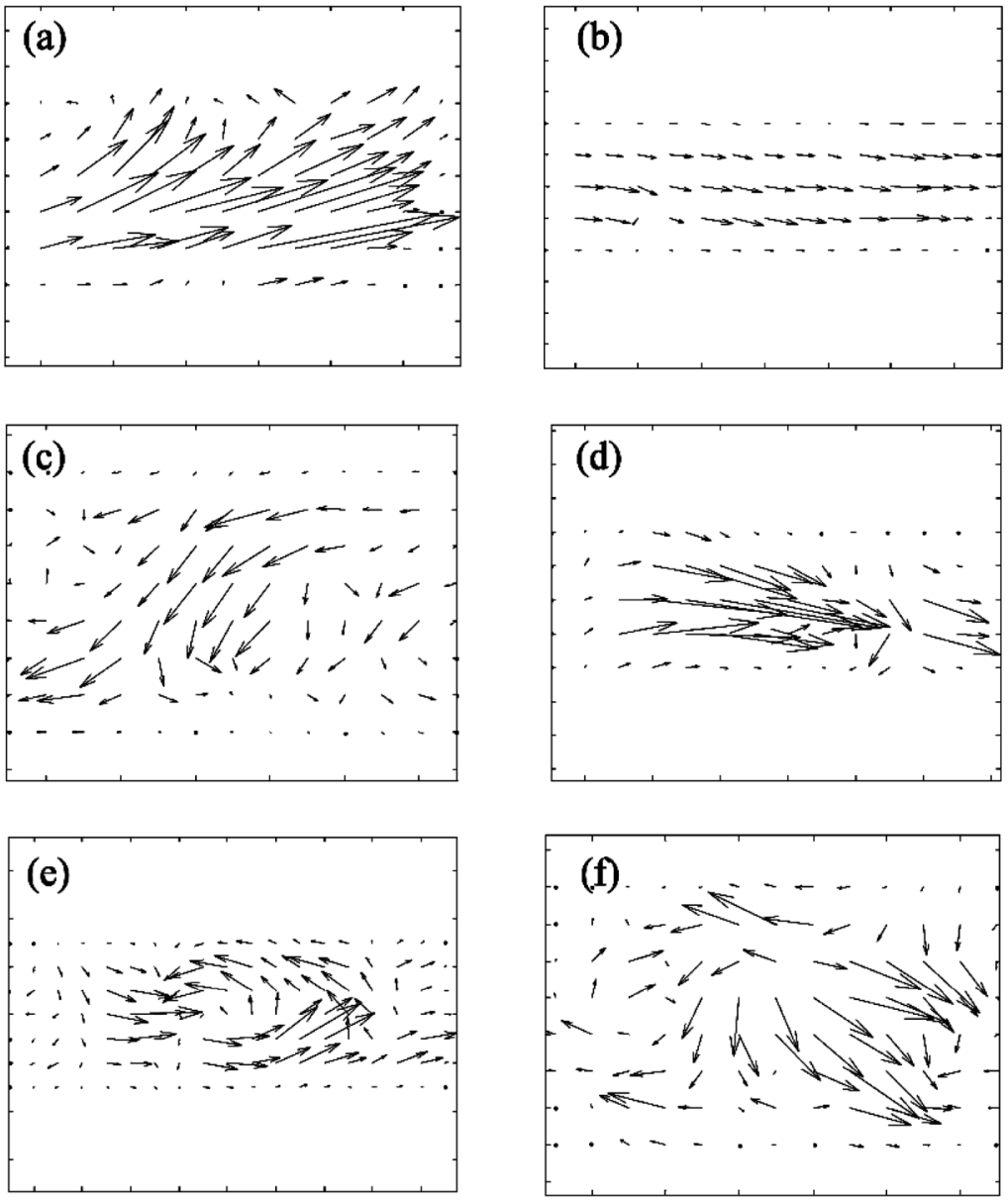

Fig. 7 Vector representations of current velocity of digested materials. 
にも関わらず，ROI 内で特定の方向への流れが見られ ない例である，ROI の中央付近から放射状に広がる様 子から，これは腸管の輪切り断面を正面に見て手前方 向に近づくように，またはその逆方向に消化物の流れ る様子が描き出されている可能性が考えられる.

Fig. 8 は, 連続約 4 秒間 (静止画枚数換算で 120 フレー 厶) の B-mode 動画像の解析結果である. Fig. 8 (a) は, 時間軸上で隣り合う2 フレーム間の消化物移動を（5） 式で定量化したグラフである。縦軸は（5）式 PAの值 で ROI 内の消化物の平均移動スピードを表し，横軸は フレーム番号である。隣り合うフレームの時間間隔は 約 $33 \mathrm{~ms}$ なので，Fig. 8 (a) は $33 \mathrm{~ms}$ ごとにプロット された四である。Fig. 8（b）と Fig. 8 （c）は，適当な 時刻の 2 フレーム間のオプティカルフロー罒である. Fig. 8 (b) がフレーム番号 25 と 26 の間のオプティカ ルフロー, Fig. 8 (c) がフレーム番号 73 と 74 の間の ものである. Fig. 8 (b) (c) の Fig. 8（a）中での位置 がそれぞれ（b）と（c）の破線枠で示されている．こ

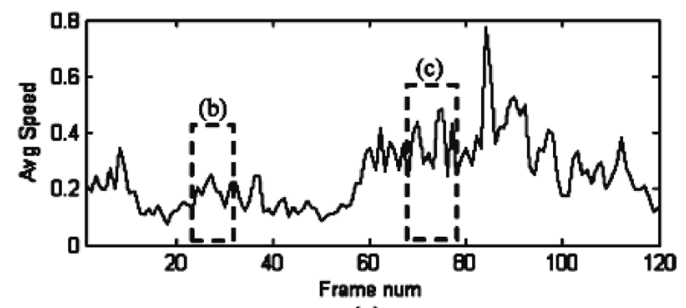

(a)

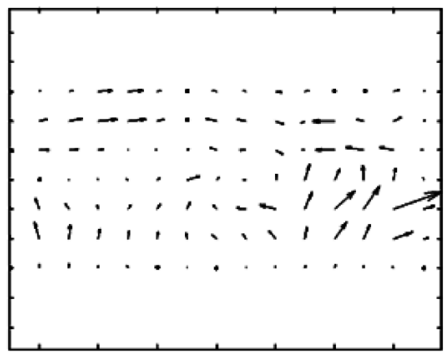

(b)

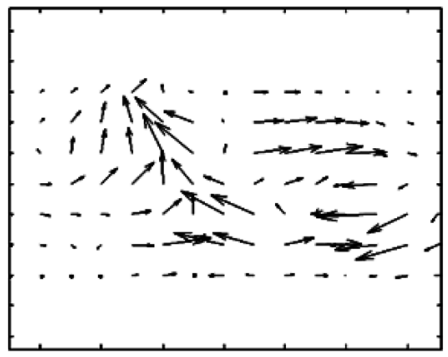

(c)

Fig. 8 An example of the quantitative analysis of peristaltic activity. (a) Average speed of current velocity vectors of digested materials. The inter-frame spacing is $33 \mathrm{~ms}$. (b) Optical flow between the frame 25 and 26. (c) Optical flow between the frame 73 and 74 .
れを見ると，オプティカルフロー中のベクトルの大き さが Fig. 8 (a) 中でグラフの増減として表現されてい る様子がわかる。

\section{4. 考察}

本提案手法では，撮影者または解析者の手作業に頼 る部分が多いが，実用上の効率や利便性を考えた時に はそれが却って都合がよい。本提案法は，小腸蠕動運 動活性の定量評価に特化した特殊なハードウェアの新 規開発を必要とせず，広く普及している既存の医療用 超音波診断装置にソフトウェアとして機能追加する形 での実用化を念頭に置いている。そのため，撮影者の 手作業に頼る部分を敢えてある程度残すことで，結果 的に撮影者・解析者の自由度と使い勝手を確保するこ とができる.

本提案法を実施するにあたり，腹腔内の小腸の走行 形状を考慮して計測を行うことは不可能である，仮に 同じ消化物移動を異なるプローブ走査で複数通り計測 することができた場合，断層像描出時の腸管の断面の とり方によって，描かれるオプティカルフローのべク トル表示は異なるものとなる。これではFig. 8（a）の ようなグラフを描いたとしても，腸蠕動運動の活性度 の絶対的定量評価を行うことにはならない。この問題 を解決する手段として，2.1節に示した手順 $(\mathrm{a}) \sim(\mathrm{j})$ のうちの（a）〜（d）を繰り返し行って消化物移動が 描出されている複数の動画・シーンを取得し，それら すべてについて（e）〜（j）の処理を施す方法が考えら れる。前述のように，本提案手法は実用化される場合 には一般的な超音波診断装置にソフトウェアとして実 装されることになるため，通常は単一のプローブで撮 影が行われる。そのため，一度に描出できる範囲は広 い腹部の一部に過ぎず，プローブの位置を変えながら 腹部の広い範囲を手動でスキャンしながら録画しなけ ればならないと考えている。そのスキャン法も手動に よるプローブ移動が行われるため，描出される腸管の 断面は確率的に特定の角度や方向に偏ることがないも のと想像される。そこで，腹部広範囲の手動スキャン によって得られるデータの提案手法による解析結果群 に対して，何からの統計的処理を行うことにより，プ ローブの当て方やその他諸々の撮影条件に起因する取 得データの偏りの上に推定される最終評価（小腸蠕動 運動活性度）と，不可観測な実際の腸管運動との誤差 を軽減できるのではないかと考えている。しかし，こ れは難しい問題であり，今後の課題である。また，主 に医用画像処理の分野に打いて B-mode 動画像解析手 法の 1 つとしてスペックルトラッキングの研究が盛ん に行われている。[19-22] スペックルトラッキングとは B-mode 動画像特有の斑模様のゆらぎや流れ・移動の 
影響を考慮して器官や組織・流体等の実体の動きを分 析する手法の総称であるが，我々の目的である消化物 移動の定量的評価に利用可能と思われる技術も開発さ れつつあるので，提案法にそれらの技術を組み込むこ とも検討する必要がある.

提案手法は, 小腸内を移動する消化物の移動量（流量） を測るための技術ではない，消化物の移動の様子から 間接的に腸管の蠕動運動の活性度を推定するための一 手法である，食品と個人の相性を調べることを目的と して，体の断面をリアルタイム動画として観察された B-mode 動画像から腸管の蠕動運動活性度を単一の指 標で表現するという研究報告は，国内外問わず他には ない. 技術的には, 造影剂を用いたX線動画像やカメ ラ内蔵小型カプセルから得られる生体情報 $[7,8]$ を利用 して，本論文と同様の目的の技術開発を行うことは可 能であると思われるが，これまでにそのような試みは 行われていない。爷れゆえ, 本提案手法の性能を他の 技術との比較によって評価することは現時点では困難 である，本提案手法の有効性の評価については，超音 波動画像判読に熟練した医師による主観的評価から始 め, 小腸の病的な異常診断に利用可能なレベルにある 技術であると認められた上で，食品の性質と個人の腸 管運動活性度との関係を膨大なデータ収集を中心に行 い，統計的に食品デザインへの応用可能性についての 評価ができる。笛の段階に至って初めて，肉体的侵襲 または精神的重負荷を伴う X 線造影やカメラ内蔵カプ セルを用いた腸管運動観察との優劣判定を行うことに なるであろう。これは今後の課題である.

\section{5. 結論}

生体信号・生体情報という客観的な指標を利用した 新しい食品デザイン技術の研究開発の一環として, 本 論文では, 腹部超音波動画像解析による小腸蠕動運動 の活性度の定量的評価法の提案を行った. 同様の目的 を持つ先行研究が無いため, 本論文は, 提案手法中で 採用されている個々の基礎技術の選択打よび運用につ いての妥当性や最適性に関する議論を今後の検討事項 として省略し,「腹部超音波動画像解析による小腸蠕動 運動の活性度の定量的評価法」という一連の完結した 流れをもつプロトタイプ技術の提案という点を主目的 としている. 提案法は, 一般的な動画像解析法として よく知られたオプティカルフローを中心に構成され, オプティカルフローのアルゴリズムは勾配法を採用し た。これにいくつかの前処理と定量化のための後処理 を加えて一連の処理手順とし, 複雑な動きをする小腸 蠕動運動の活性度を単一のものさしで表現する基礎的 な方法を構築した。

本提案法は B-mode 動画像の取得条件や撮像方法に
よって解析結果が大きく異なると考えられるため，超 音波プローブの最適な操作法の確立, およびプローブ 操作技術の違いが結果に大きく影響を与えないような 統計的手法による事後处理法の検討などが，今後解決 すべき課題として挙げられる.

\section{謝 辞}

本研究の一部は, 文部科学省科学研究費補助金（基 盤研究 (B)), 打よび独立行政法人科学技術振興機構研 究成果展開事業研究成果最適展開支援プログラム FS ス テージ探索タイプの援助により行われた。ここに記し て謝意を表す。

\section{引 用 文 献}

1) O. Sakata, S. Kaneko, S. Tange, T. Satake, S. Suzuki; "Evaluation of Food Quality Based on Digestive Activities of Small Intestine -Analysis of Bowel Sound and Automatic Detective System of Bowel Sounds-"(in Japanese). Japan J. Food Eng., 5, 113-119 (2004).

2) O. Sakata, Y. Togawa, S. Kaneko, T. Satake; "Evaluation of Food Quality based on Digestive Activities of Small Intestine -Accuracy of Bowel Sound Detection by Multidimensional Signal Processing-"(in Japanese). Japan J. Food Eng., 9, 51-57 (2008).

3) O. Sakata, Y. Togawa, H. Hashimoto, T. Satake; Alteration in bowel sound depending on the type of food. J. Clin. Biochem. Nutr., 43 Supple. 1, 279-581 (2008).

4) O. Sakata, Y. Togawa, K. Matsuda, T. Satake; Long-time measurement and temporal change analysis of bowel sound for observation of enterokinesis. Proc. of the Int. Conf. on Electrical Eng., P-167, 1-4 (2008).

5) O. Sakata, T. Satake; Integration of different types of biological signals-bowel sound and salivary amylase-- Proc. of 2010 ASABE Ann. Int. Meeting, Paper no. 1009687, 1-5 (2010).

6) O. Sakata, Y. Suzuki, K. Matsuda, T. Satake; "Robust Bowel Sound Recording System for Long-term Monitoring of Digestive Activity" (in Japanese), J. Japan Soc. Welfare Eng., 12, 43-48 (2010).

7) J. Gerber, A. Bergwerk, D. Fleischer; A capsule endoscopy guide for the practicing clinician: technology and troubleshooting. Gastrointestinal endoscopy, 66, 1188-1195 (2007).

8) D. K. Iakovidis, S. Tsevas, A. Polydorou; Reduction of capsule endoscopy reading times by unsupervised image mining. Computerized Med. Imag. Graph., 34, 471-478 (2010). 
9) B. K. P. Horn, B. G. Schunck; Detecting optical flow. Artificial. Intelli., 17, 185-203 (1981).

10) J. L Barron, D. J. Fleet, S. S. Beachemin; Performance of optical flow techniques. Int. J. Comput. Vision, 12, 43-77 (1994).

11) A. Nomura, H. Miike, K. Koga; Field theory approach for determining optical flow. Patt. Recog. Lett., 12, 183-190 (1991).

12) A. Bainbridge-Smith, R. G. Lane; Determining optical flow using a differential method. Image Vision Comput., 15, 11-22 (1997).

13) J. W. Brandt; Improved accuracy in gradient-based optical flow estimation. Int. J. Comput. Vision, 25, 1-22 (1997).

14) J. K. Kearney, W. B. Thompson, D. L. Boley; Optical flow estimation: An error analysis of gradient-based methods with local optimization. IEEE Trans. Patt. Anal. Mach. Intell., 9, 229-244 (1987).

15) L. Brown; A survey of image registration techniques. ACM Comput. Surveys, 24, 325-376 (1992).

16) P. Van den Elsen, E. -J. Pol, M. Viergever; Medical image matching - a review with classification. IEEE Eng. Med. Biol., 12, 26-39 (1993).

17) J. Maintz, M. Viergever; A survey of medical image registration. Med. Image Analysis, 2, 1-36 (1998).

18) H. Lester, S. Arridge; A survey of hierarchical non-linear medical image registration. Patt. Recog., 23, 129-149 (1999).

19) J. W. H. Korstanje, R. W. Selles, H. J. Stam, S. E. R. Hovius, J. G. Bosch; Development and validation of ultrasaound speckle tracking to quantify tendon displacement. J. Biomecha., 43, 1373-1379 (2010).
20) F. Yeung, S. F. Levinson, K. J. Parker; Multilevel and motion model-based ultrasonic speckle tracking algorithms. Ultrasound in Med. \& Biol., 24, 427-441 (1998).

21) W. Aoudi, H. Liebgott, A. Needles, V. Yang, F. S. Foster, D. Vray; Estimation methods for flow imaging with high frequency ultrasound. Ultrasonics, 44, 135-140 (2006).

22) D. H. Cooper, B. R. Madsen, J. Graham; Estimating Motion in Ultrasound Images of the Small Bowel: Optical Flow without Image Structure. Lecture Notes in Comput. Sci., 2749/2003, 31-42 (2003).

\section{和文要 旨}

食品デザインの場に生体情報に基づく食品評価技術 を導入することにより，付加価值の高い食品開発が可 能になるはずである。我々は消化器官の中でもとくに 小腸に注目し，小腸の消化活動の活性度が個人の体質 や健康状態と摂取した食品との相性によって変化する と考え，小腸の蠕動運動活性度を指標とした個人の体 質・体調に適した食品のデザインに利用できる基礎技 術を提案する。国内医療機関では超音波診断装置が広 く普及し，消化管の状態や運動を観察する技術が確立 されているが，その技術体系は主に臓器の異常を発見 するためのものであり，正常に働く臓器を詳細に観察 するために構築された技術ではない。しかし我々の目 的は，健常者から重症患者までの様々な状態にある人 間を対象とした，消化活動モニタリング技術の開発で ある。そこで，超音波動画像処理によって小腸が消化 物を移動させていく蠕動運動の様子を 1 つの物差しで 定量的に表現する方法を考案した. 